of invertebrate larvæ, mostly prepared by Mr. W. Rogers, laboratory steward, from the fine collection of microscope slides of marine larvæ made at Port Erin by the late Mr. H. C. Chadwick and purchased from him. Gastropod development is illustrated by copies of Dr. Doris Crofts's models of Haliotis larvæ.

Among the Museum's treasures are numerous delicate preparations of medusæ, corals and sea-pens with polyps expanded, from Naples Marine Biological Laboratory, preserved especially for the Museum by Cavaliere Salvatore Lo Bianco. They were probably the last specimens preserved by that greatest of preparators of marine material.

At one time the Museum of the Royal College of Surgeons, with its long history from Hunter to
R. H. Burne, was Reading's nearest parallel and exemplar ; but this was destroyed by bombs in the Second World War. The Cole Museum was built up probably in the last years when such things were possible. Thirty years ago it was adequately housed in the room which it still occupies, and now congests. It is greatly to be hoped that on the new University site. a worthy building will be planned for the Cole Museum and that provision will be made to maintain what is a unique asset, not only for the University of Reading, but also for the entire country. Since this project may be many years ahead, we look to the University authorities to preserve the Museum intact, perhaps, if necessary, in a temporary building big enough for the whole collection to be adequately displayed and used.

\title{
OBITUARIES
}

\section{Prof. Kurt G. Stern}

KuRt G. Stenn died on February 3 of a heart attack in St. Mary's Hospital, London, in his fiftyfirst year. Born in Tilsit, he attended elementary and grammar school there and moved to Berlin for his higher education, where he received his Ph.D. in 1930 at the University. In the following year he won a Rockefeller fellowship, worked for one year at the Rockefeller Institute in New York, and for two more years at the Courtauld Biochemical Institute in London. When he was to return to Germany in 1935, the Nazis had taken over and Dr. Stern decided to accept a research fellowship at Yale University in New Haven, where he became a research associate in 1938 and joined the Overly Research Foundation in 1942. Two years later he was offered a post as research associate and adjunct professor at the Polytechnic Institute of Brooklyn, in which position he remained until his death.

Stern's influence on the development of biochemistry rested on the combination of several distinguished qualities : he was an excellent lecturer and an inspiring teacher; he was a meticulous experimentalist with an innate urge for precision and accuracy, and on top of it all he had a neverfailing flair for selecting problems of general im. portance and far-reaching significance. He was strongly attracted by questions connected with the fundamental aspects of life, and hence biochemistry, biology and physiology were the sources from which he selected his problems; but with equal firmness he adhered to the exact quantitative and reproducible methods of physical chemistry and physics. As a consequence, for many years, his activities developed in the borderland between different sciences, taking problems from one and solving them with methods taken from another. In this difficult, self-assigned task, Stern succeeded not only in introducing precise methods in fields where they were unknown, but also in inventing and constructing many new instruments for the purification and characterization of biological objects, particularly enzymes, virus, proteins and nucleic acids.

While he worked and taught at the Polytechnic Institute of Brooklyn, he also acted as chemical consultant at the Montefiore Hospital in the Bronx; and it was a fitting expression of his constant tendency to bridge gaps between different sciences that each day he moved in the morning through the corridors of a busy hospital at one end of New York's metropolitan area, and in the afternoon lectured and supervized fundamental research in the laboratories of the Polytechnic Institute of Brooklyn at the other end. This type of work he liked; thus he contributed innumerable important results, and in both fields he was highly esteemed and liked by his colleagues and collaborators.

Dr. Stern's activities and efforts won him many recognitions and honours. He served as chairman of the Protein and Nucleic Acid Week of the Gordon Research Conferences; he was the secretary of the Planning Committee of the Chaim Weizmann Institute in Rehovoth; he was president of the American Society of European Chemists and Pharmacists and he served on many occasions as chairman of special symposia arranged by the American Chemical Society, the Now York Academy of Sciences and in other scientific and technical organizations. He was awarded in 1953 the Pasteur Medal of the French Society of Chemistry and Biology.

His great scientific achievements and professional success were equalled by his warm, friendly and helpful personality. Everybody who came into contact with Dr. Stern was impressed by his high ideals, his devotion to the cause of science and his unfailingly doep interest in social and human relationships.

H. MARK

\section{Mr. Horatio Ballantyne}

Horatro Batlantyne, who died on January 25 at his home at Tadworth, Surrey, in his eighty-fifth year, was a consulting chemist and expert witness in patent cases whose theoretical knowledge was firmly buttressed by wide practical experience. His transfer from this field of activity to the Board of Lever Bros. in 1928, while at the height of his powers, though doubtless of benefit to commerce and industry generally and to that great Company in particular, left a gap in the ranks of scientific witnesses, and when, a few years later, his boyhood friend, Sir Dugald Clerk, the patent agent and expert on internal combustion engines and gaseous fuels, passed away, the fundamental contribution which they had made to the administration of the patent law was demonstrably evident. In engineering matters, Sir James Swinburne, the late Mr. H. A. Gill and Horatio's younger brother, the late $\mathrm{Mr}$. W. H. Ballantyne, 
provided an adequate complement; but their gallant efforts to assist in cases arising in other scientific fields only made it more manifest that the day of the comprehensive scientific expert witness had come to an end.

The Reports of Patent Cases bears witness to Ballantyne's amazing versatility. From his début in the famous Welsbach gas mantle litigation, he assumed the burden of scientific exposition in patent cases for more than thirty years, dealing with topics as diverse as gramophones, electric lamps and filaments, steel ball grinders, coal-cutting machines, typewriters, confectionery, the drying of milk and a host of others. The first encomium he received was in his first case and came from Mr. Justice Wills, who said in his judgment: "I wish to add that $\mathrm{Mr}$. Ballantyne has given me reason to rely on him. $\mathrm{He}$ is one of the most truthful and fairest minded men I have seen in the witness box". The last to my know ledge appears in an appreciation by Sir Kenneth Swan, a distinguished leader of the Patent Bar and himsolf a son of a great inventor. He wrote: "His evidence, invariably characterized by scrupulous candour and fairness, was not only backed by profound technical knowledge, but was always based on a careful and crucial experiment; moreover it was given with that degree of precision and tenacity that rendered it proof against the most penetrating crossexamination. In short, he was a pattern of what an expert witness should be". Both, it will be noted, remarked Ballantyne's candour and fair-mindedness, two attributes which the experienced judge will thankfully recognize, and without which the most profound scientific knowledge will fail to impress. The value of an expert witness resides in the weight attached to the expression of his opinions. He must, of course, be technically competent and preferably free from addiction to technical jargon. But in the ultimate result, his assistance in the administration of justice will depend not only upon his perception and expression of truth, but upon the manner in which he completes and isolates it. In this Ballantyne was pre-eminent, and that explains why it was that, in cases involving scientific questions with which he was only generally familiar, his assistance was often more valuable than the evidence of more specialized experts.

Horatio Ballantyne was born at Glasgow in 1871 . His father, Thomas Ballantyne, who was a pioneer of unitarianism in Glasgow, was married twice, and had thirteen children, Horatio being the eldest son and first child of the second marriage. His father died when Ballantyne was fifteon years old.

At fourteen he left school to begin work in the laboratory of Robert Tatlock, city analyst for Glasgow. It had been planned that he should go to the University, having gained a bursary that would have enabled him to do so, but the young Ballantyne resigned the bursary and went to Tatlock's, starting at a wage of $2 s$. per week.

It was a very busy commercial laboratory, with a large Students' Department attached, and gave a really extensive training in industrial chemical analysis. After some time Ballantyne became chief assistant, and Tatlock and his partner Thompson invited him to become, in 1898, a member of the firm when Dr. J. B. Readman was due to retire; but brighter prospects came his way.

During the years with Tatlock, he had opportunities for carrying on research, especially into the little-understood chemistry of the oils and fats. Some accounts of these investigations were published in the Journal of the Society of Chemical Industry. In the evenings he attended classes in chemistry, mineralogy, German, etc. $\mathrm{He}$ took first place in Great Britain in the 'South Kensington' examination in honours ehemistry, and the first place also (with medal) in the Society of Arts examination in German.

In March 1896 occurred an event which determined the course of his professional life. A few years before that date, Tatlock had received from Norway some samples of minerals which were to be tested for what was then known as the "rare earths", especially yttrium, cerium, lanthanum and thorium oxides. The invention of the incandescent gas mantle by Auer von Welsbach had given a special value to such earths, the chemistry of which was quite unknown to chemists in general. Tatlock had passed on to Ballantyne the problem of working out methods of analysis, etc., and he became in a small way a specialist in this recondite subject.

The Welsbach Incandescent Gas Light Co. of London acquired the rights to the British Welsbach patents, and by the year 1895 had become so successful that many infringing manufacturers appeared. An action for infringement of patent was brought against one of them. Towards the end of October 1895 a specimen of the infringing article was sent to Tatlock for analysis, and as it was said to be made of the rare earths he handed over the problem to Ballantyne. In March 1896 Ballantyne was asked unexpectedly to proceed immodiately to London to be present at the trial of the action. The case began before Mr. Justice Wills. Fortunately for Ballantyne, it turned out to be the most important case of the time. The principal leaders of the Patent Bar were ongaged in it, as were the leading expert witnesses (Sir Henry Roscoe, Prof. (Sir) James Dewar, Dr. Otto Hehner, (Sir) James Swinburne, Dr. Dupre, (Sir) Dugald Clerk, John Murrey, Prof. Vivian B. Lewes, Prof. Lambert, etc.). Leading counsel for the patentee was J. Fletcher Moulton (afterwards Lord Moulton), at that time the most distinguished counsel at the Patent Bar. The trial of the action was very protracted. Most of the work on the controversial matters fell upon Ballantyne's shoulders and he worked feverishly, night and day. Three times he was called to the witness-box. Such was the event which began Ballantyne's career as an expert witness and led him to specialize in patents and cognate matters.

Ballantyne was elected vice-president of the Institute of Chemistry in 1918, and again for the years 1920-22. He served on a number of Board of Trade departmental committees dealing with patent, law and practice and with inventions made in government service. He married in 1899 Miss $\mathrm{K}$. Russell, who survives him with the three daughters of the marriage.

G. H. LLOYD-JACOB

\section{Mr. D. B. Waters}

DaviD Bowe Waters, whose death occurred on February 7 at Glasgow at the age of forty-three, was a civil engineer and was responsible during the Second World War for much of the detailed technical development at the Road Research Laboratory (Department of Scientific and Industrial Research) of the devices known as 'plastic armour' and 'plastic protective plating' : these materials were used on most of the Allied merchant ships for the protection of vital parts 